\title{
The more things change, the more they stay the same.
}

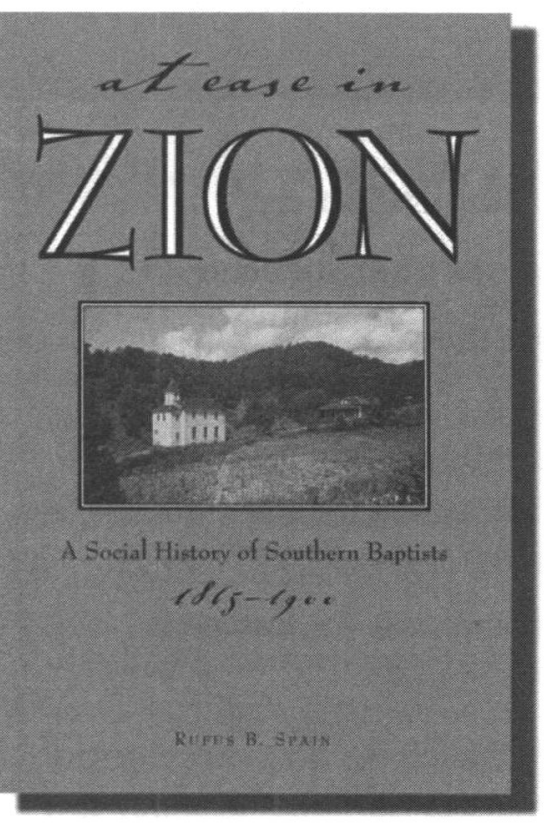

\section{At Ease in Zion}

A Social History of Southern Baptists, 1865-1900

RUFUS B. SPAIN

WITH A FOREWORD BY SAMUEL S. HILL

With a title that references the biblical description of peace and prosperity, this book examines attitudes of Southern Baptists (and their denomination and convention) toward the profound social, moral, economic, and political changes the South faced in the postCivil War era.

"A balanced view of southern history, [At Ease in Zion] is evidence of a new spirit of selfcriticism among Southern Baptists and will be a useful source for students of southern society and religion."

- Journal of American History

280 pages ISBN 0-8173-5038-1 \$20.00s paper
Quest for a Christian America, 1800-1865

A Social History of the Disciples of Christ, Volume 1

\section{Sources of Division in} the Disciples of Christ, 1865-1900

A Social History of the Disciples of Christ, Volume 2

DAVID EDWIN HARRELL JR.

WITH A NEW PREFACE BY THE AUTHOR

The definitive social history of the Disciples of Christ in the 19th century.

"According to Harrell, sociological factors, not religious norms, determined ultimately how most Disciples responded to industrialism and an ever-increasing secularism in American society."

- American Historical Review

Volume 1

280 pages ISBN $0-8173-5074-8 \quad \$ 19.95$ s paper

Volume 2

480 pages ISBN0-8173-5075.6 \$29.95s paper

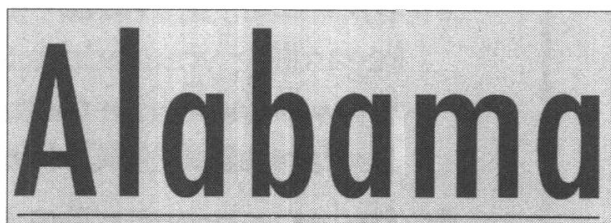

THE UNIVERSITY OF ALABAMA PRESS

$$
\text { Life is short. }
$$
Read good books.

Fax Orders: (773) 660-2235 or (800) 621-8476

Orders: (773) $568-1550 \cdot$ www.uapress.ua.edu 


\section{ASCH IS NOW ON THE WEB}

- Obtain information about membership and subscription

- Confirm dates and places of future meetings

- Learn criteria for submissions to Church History

- Verify requirements and deadlines for prizes

- Place announcements about calls for papers, grants, and competitions, personal items, etc., in our newsletter

- Enter your own questions, responses, professional concerns, etc., on our bulletin board

- Plus other features to aid your search

Visit us at www.churchhistory.org

\section{RECENT ADDITIONS}

- Member Services - log in to add or revise data regarding your address, email, and topical interests; browse the entire membership list for such information about all $\mathrm{ASCH}$ members

- Index-browse the list of all articles published since 1889; search by either author's last name or key word in titles 


\section{WARRIORS OF THE LORD}

THE MILITARY ORDERS OF CHRISTENDOM

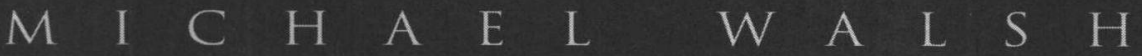

\section{A History Book Club alternate selection}

7 he great religious orders of Christianity — the Benedictines, the Dominicans, the Franciscans, the Jesuits - are well

1 known for their monasteries, their learning, and their missions around the world. But in the Middle Ages and beyond, there was another kind of religious order whose purpose it was to bear arms in defense of Christendom. This lavishly illustrated, oversized book tells the extraordinary story of the military orders of the Church.

Coupling a compelling narrative with striking historic art, Michael Walsh examines the development, beliefs, spirituality, and cultural contributions of these determined soldier-monks. Walsh draws on a wide range of historical documents, introducing readers to the mission, lifestyles, writings, and buildings of the various military orders and highlighting their spiritual, intellectual, artistic, and educational legacies.

A fascinating and informative read, Warriors of the Lord will thrill anyone interested in Christian or cultural history.

WARRIORS OF THE LORD

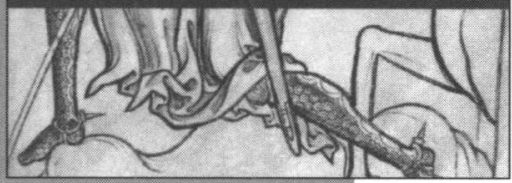

At your bookstore, or call 800-253-7521 www.eerdmans.com
Over 100 illustrations ISBN 0-8028-2109-X hardcover $\$ 30.00$

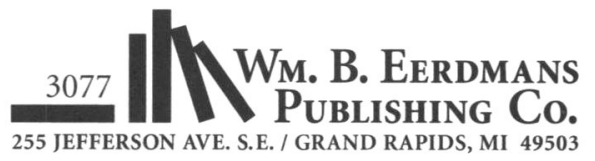




\section{New Books from Tennessee!}

Dark Symbols, Obscure Signs

God, Self, and Community in the Slave Mind

Riggins R. Earl Jr., with a new introduction

264 pp., paper ISBN 1-57233-217-4, \$22.50

\section{traceful Women}

Gender and Identity in an American Sikh Community Constance Waeber Elsberg

408 pp., cloth ISBN 1-57233-214-X, $\$ 35.00$

Mountain Holiness

A Photographic Narrative

Deborah Vansau McCauley \& Laura E. Porter, with Patricia

Parker Brunner; photographs by Warren E. Brunner

210 pp., 350 photos, paper ISBN 1-57233-208-5, $\$ 28.00$

Waiting for Elizah

A History of the Megiddo Mission

Gari-Anne Patzwald, foreword by Charles H. Lippy 280 pp., illustrations, cloth ISBN 1-57233-209-3, \$30.00

\section{Authority and Reform}

Religious and Educational Discourses in

Nineteenth-Century New England Literature

Mark Vásquez

416 pp., cloth ISBN 1-57233-213-1, \$38.00

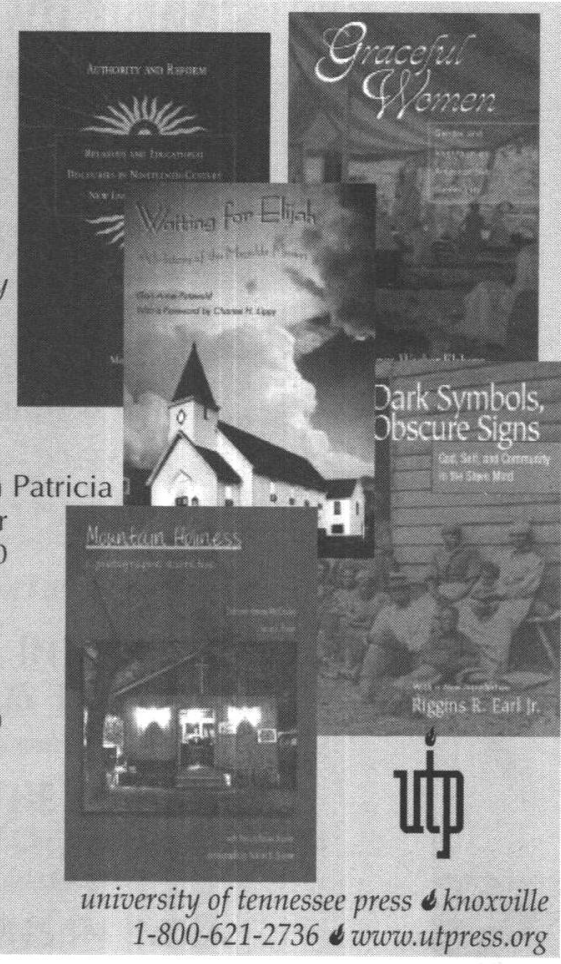




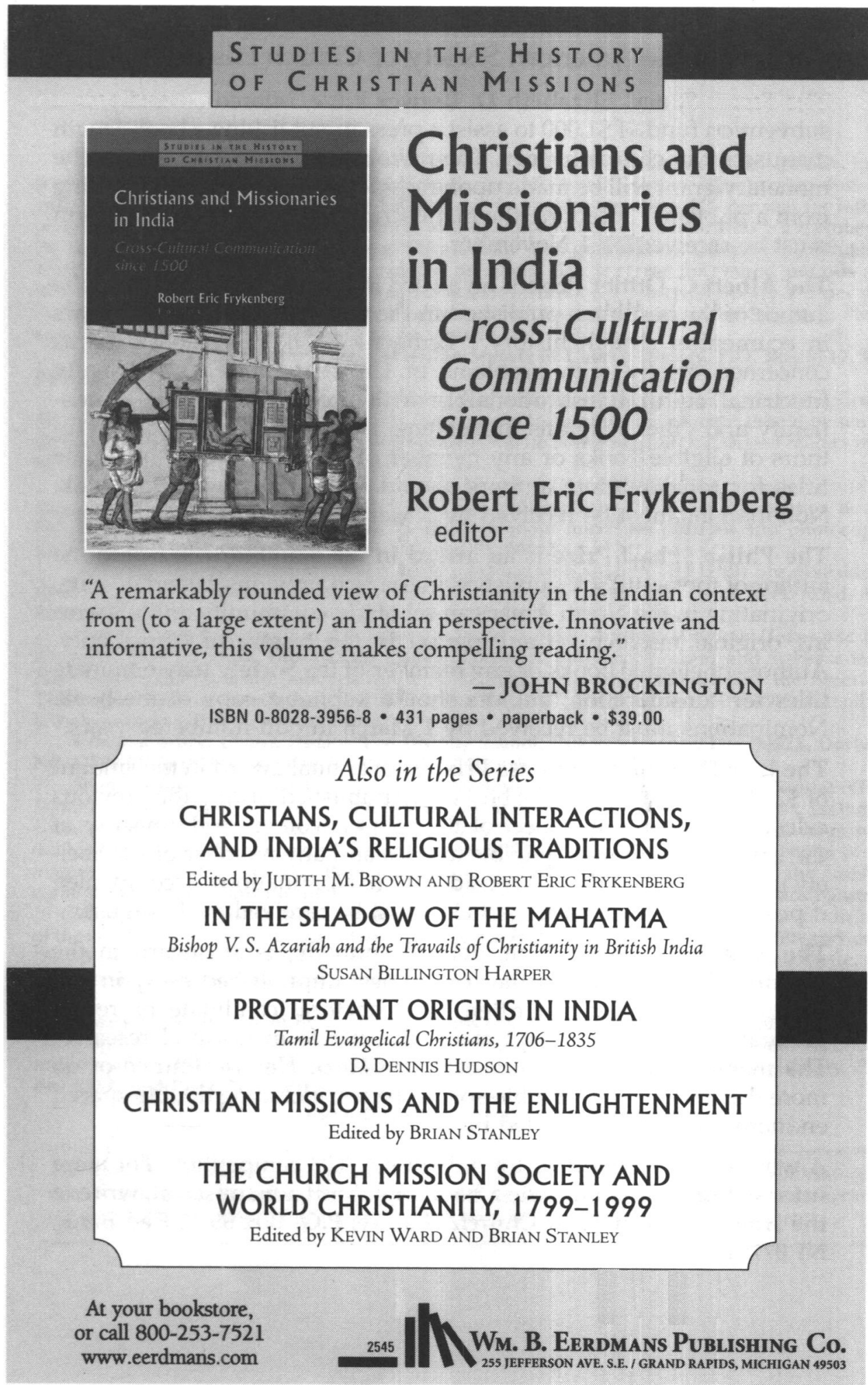




\section{Awards of the American Society of Church History:}

The Frank S. and Elizabeth D. Brewer Prize, offered annually, is a subvention fund of $\$ 1,000$ to assist a press in publishing a book-length manuscript in church history. The prize is limited to first books. The monetary grant will be made upon receipt of a commitment in writing from a publisher accepting the manuscript. Entries in their final form must be received by 1 November.

The Albert C. Outler Prize is an award in the amount of $\$ 1,000$ to the author of the best book published in the two previous calendar years in ecumenical church history. "Ecumenical" is to be construed as concerned chiefly with problems of Christian unity and disunity (doctrinal, cultural, institutional) or with interactions between Christianity and other religious movements in any historical period. Authors of eligible books or any member of the Society may nominate titles for consideration; authors should submit a copy of the book. Nominations must be received by 1 March in even-numbered years.

The Philip Schaff Prize is an award in the amount of $\$ 1,000$ to the author of the best book published in the two previous calendar years, originating in the North American scholarly community and presenting original research on any period in the history of Christianity. Authors of eligible books or any member of the Society may nominate titles for consideration; authors should submit a copy of the book. Nominations must be received by 1 March in odd-numbered years.

The Jane Dempsey Douglass Prize is an annual award in the amount of $\$ 250$ for the author of the best essay published during the previous calendar year on any aspect of the role of women in the history of Christianity. Authors of eligible articles and any member of the Society may nominate titles for consideration. Nominations, accompanied if possible by a copy of the article, must be received by 1 August.

The Sidney E. Mead Prize, offered annually, is an award in the amount of $\$ 250$ for the author of the best unpublished essay in any field of church history written by a doctoral candidate or recent graduate whose manuscript stems directly from doctoral research. The manuscript will be published in Church History. Entries of no more than twenty-five double-spaced pages, including double-spaced endnotes, must be submitted by 1 July.

A work may be submitted for only one ASCH competition. For more information, or to nominate a book or submit a manuscript, write to the American Society of Church History, P.O. Box 8517, Red Bank, NJ 07701. 
Church History: Studies in Christianity and Culture is published four times per year (March, June, September, and December) by the American Society of Church History. Membership dues for individuals in the U.S. and Canada are $\$ 50$ per year for regular members, $\$ 25$ per year for retired persons, and free for two years for students with the approval of a professor who is a member of the Society (after two years, students pay $\$ 25$ annually until graduation). Dues for individuals in other countries are $\$ 75$ per year for regular members, $\$ 30$ per year for retired persons and students (with the same two-year gratis stipulations). Institutional subscriptions are $\$ 75$ per year in the U.S. and Canada, $\$ 100$ per year in all other countries. Single issues are $\$ 25$ each. Please make remittances payable to "American Society of Church History."

Office of the executive secretary: American Society of Church History, P.O. Box 8517, Red Bank, NJ 07701-8517.

Subscription applications, renewals, changes of address, claims for missing numbers, orders for single copies of current or back issues, and requests for permission to quote should be sent to the executive secretary. Claims for missing numbers will be honored without charge if made within two months of the regular month of publication.

Microfilm reproductions of The American Society of Church History Papers, series I and II, and of Church History, volumes 1-17 (1932-48), are available from the ATLA Preservation Board. Orders for these reproductions as well as inquiries about microfilm portions and photocopies should be sent to 1118 East 54th Place, Chicago, IL 60615.

Microfilm reproductions of Church History starting with volume 18 (1949) are available to subscribers and members of the Society from University Microfilms, 300 North Zeeb Road, Ann Arbor, MI 48106.

Church History is indexed in the Expanded Academic Index (Infotrac), American History and Life, Arts and Humanities Search, Web of Science, Historical Abstracts, Religious Periodicals, and Academic Search Elite. This periodical is also indexed in the ATLA Religion Database, published by the American Theological Library Association, 250 S. Wacker Dr., $16^{\text {th }}$ Flr., Chicago, IL 60606; E-mail: at la@atla.com,www:http://www.atla.com/.

Editorial office: Church History, The Divinity School, Duke University, Box 90975, Durham, NC 27708-0975; (919) 660-3470; fax (919) 660-3473; church-history@duke.edu.

Send manuscripts, books for review, and requests about advertising to the editorial office. Manuscripts should run 6,000-11,000 words (or approximately 20-35 pages), not including endnotes, and should be printed double-spaced in 11-or 12-point font; endnotes must be printed double-spaced on separate pages following the text. The editors request (1) three copies of the manuscript (in order to protect the author's anonymity during the review process, the author's name should appear only on the title page of the essay); (2) three copies of a 200-word abstract (if Church History publishes the essay, the abstract may be printed above the first line of the text of the article and/or it may be included on the Church History web page at www.churchhistory.org); (3) a 31/2-inch diskette containing the manuscript and abstract (instead of sending a diskette, you may submit your manuscript and abstract by electronic mail). Further guidelines are available on request.

Church History is printed by the Science Press division of Cadmus Professional Communications, Ephrata, Pennsylvania. Periodicals postage paid at Red Bank, New Jersey and additional mailing offices. Postmaster: Send address changes to American Society of Church History, P.O. Box 8517, Red Bank, NJ 07701.

\section{ChURCh History (ISSN 0009-6407)}

The opinions expressed in this journal represent the views only of the individual contributors; they do not necessarily reflect the views of the editors, Duke University, or the American Society of Church History. Advertising in Church History does not necessarily imply endorsement. 


\section{CONTENTS}

457 Religious Poverty, Mendicancy, and Reform in the Late Middle Ages

Michael D. Bailey

484 Trinitarian Love Mysticism: Ruusbroec, Hadewijch, and the Gendered Experience of the Divine Jessica A. Boon

504 Melanchthonian Method as a Guide to Reading Confessions of Faith: The Index of the Book of Concord and Late Reformation Learning Robert Kolb

525 Was There a Reformation in the Sixteenth Century?

Hans J. Hillerbrand

553 The Colonization of British North America as an Episode in the History of Christianity Charles L. Cohen

569 The "African Enslavement of Anglo-Saxon Minds": The Beechers as Critics of Augustine Peter J. Thuesen

593 Conservative American Protestantism in the League of Nations Controversy

Markku Ruotsila

617 Book Review Forum

634 Book Review Essay

639 Book Reviews and Notes

692 Society Notices 